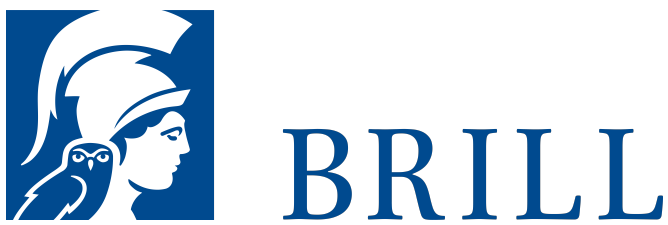

\title{
Emotions Hold the Self Together
}

\author{
Self-Consciousness and the Functional Role of Emotion
}

Author: Alexandra Zinck

While classical philosophy of mind regards cognitive faculties, such as consciousness, attention and emotions, as autonomous modalities, modern neuroscience teaches us that these should be considered with respect to the experiencing self. Fear, anger, joy or sadness should not be considered as distinct phenomena but in relation to the self which experiences them on the one hand and expresses them on the other. This book endeavours to draw a framework of self-referential emotions as a plane in which the self is active. Using notions from classical and modern analytical philosophy of mind as well as findings from cognitive psychology and neuroscience, the main idea presented here is that emotions, and self-referential emotions in particular, are essential for the constitution of the self. Emotions provide the self with evaluative information about the self's faring in the world. Moreover, by facilitating communication with other 'selves', emotions further promote understanding of other's evaluations of the self, enhancing the development of a self-concept and conscious self-experience. It is proposed that highly salient emotional self-reference and evaluative selfexperience are at the core of various levels of selfconsciousness. Self-referential emotions therefore might have implications for understanding one's behavior as well as its breakdown in various pathologies such as...

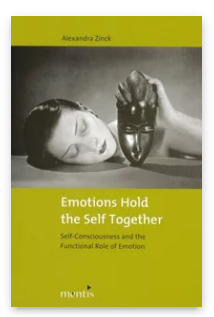

Pages: 185

Seiten

Language:

English

Subjects:

General,

Philosophy

Publisher: Brill | mentis

E-Book (PDF)

Released online:

o1 Mar 2011

ISBN: $978-3^{-}$

95743-928-4

List price

USD \$48.0o

Paperback

Publication date:

o1 Mar 2011

ISBN: 978-3-

89785-704-9

List price

USD \$ $\$ 48.00$ 
For more information see brill.com

Order information: Order online at brill.com +44330 333 0049 | customerservices@brill.com Submission information: brill.com/authors

Titles published by Brill | Fink, Brill | mentis or Brill | Schöningh: +49(o)715413279216| brill@brocom.de 